\title{
Translation and adaptation of a questionnaire on the needs of postpartum adolescents
}

Tradução e adaptação de questionário sobre necessidades das mães adolescentes no pós-parto

Traducción y adaptación de cuestionario sobre necesidades de las madres adolescentes en el posparto

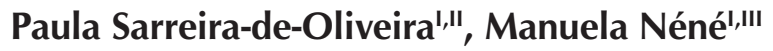 \\ ' Universidade Católica Portuguesa, Health Sciences Institute. Lisbon, Portugal. \\ "Escola Superior de Enfermagem Egas Moniz, Nursing Department. Lisbon, Portugal. \\ III Cruz Vermelha Portuguesa, Health College. Lisbon, Portugal.
}

\begin{abstract}
How to cite this article:
Sarreira-de-Oliveira P, Néné M. Translation and adaptation of a questionnaire on the needs of postpartum adolescents. Rev. Bras. Enferm. [Internet]. 2018;71(3):992-7. DOI: http://dx.doi.org/10.1590/0034-7167-2017-0021
\end{abstract}

Submission: 03-20-2017 Approval: 05-21-2017

\begin{abstract}
Objective: Describe the processes of translation to the Portuguese language and cultural adaptation of the Postpartum Learning Needs (PLN) to the Portuguese context. Method: Methodological study of an instrument that was constructed and validated in Jordan. Here are presented the procedures referring to linguistic, semantic and cultural validation, involving the stages of translation from English to European Portuguese, synthesis of translations, back-translation to the original language, expert committee, and pre-testing. Results: In the translation process, some vocabulary variations were solved through consensus among translators. The expert committee found that the version translated to Portuguese presented semantic, idiomatic, cultural and conceptual equivalence, while needing some adjustments. Pre-testing was applied to 45 adolescent mothers, of whom $86.6 \%$ considered the items comprehensible. Conclusion: Semantic, idiomatic, cultural and conceptual equivalences were conceptually satisfactory among questionnaire versions, which is relevant for the Portuguese culture and easily understandable. It is crucial to assess the psychometric properties of the questionnaire so its adapted version can be made available.
\end{abstract}

Descriptors: Translation; Parenting; Health Services Needs and Demands; Problem-Based Learning; Adolescent.

\section{RESUMO}

Objetivo: Descrever os processos de tradução para a língua portuguesa e adaptação cultural do Pospartum Learning Needs (PLN) para o contexto português. Método: Estudo, de tipo metodológico, de um instrumento que foi construído e validado na Jordânia. Apresentamos os procedimentos referentes à validação linguística, semântica e cultural, compreendendo as etapas de tradução do inglês para o português europeu, síntese das traduções, retrotradução para a língua de origem, comissão de peritos e pré-teste. Resultados: No processo de tradução, algumas variações vocabulares foram solucionadas através do consenso entre os tradutores. A comissão de peritos considerou que a versão traduzida para o português apresentou equivalência semântica, idiomática, cultural e concetual, mas apresentando necessidade de alguns ajustes. O pré-teste foi aplicado a 45 mães adolescentes, das quais $86,6 \%$ consideraram os itens compreensíveis. Conclusão: Houve equivalências semântica, idiomática, cultural e concetual satisfatórias entre as versões do questionário, o qual é pertinente à cultura portuguesa e facilmente compreensível. No entanto, para que o questionário adaptado seja disponibilizado, é imprescindível avaliar as propriedades psicométricas.

Descritores: Tradução; Poder Familiar; Necessidades e Demandas de Serviços de Saúde; Aprendizagem Baseada em Problemas; Adolescente.

\section{RESUMEN}

Objetivo: Describir los procesos de traducción al portugués y adaptación cultural al contexto portugués del Pospartum Learning Needs (PLN). Método: Estudio metodológico de un instrumento construido y validado en Jordania. Presentamos los procedimientos referentes a su validación lingüística, semántica y cultural, comprendiendo las etapas de traducción del inglés al portugués europeo, síntesis de traducciones, retrotraducción, comisión de peritos y prueba piloto. Resultados: En el proceso de traducción, ciertas variaciones en el vocabulario fueron zanjadas por consenso entre los traductores. La comisión de peritos consideró que la versión 
traducida al portugués mostró equivalencia semántica, idiomática, cultural y conceptual, aunque precisando de correcciones. La prueba piloto fue aplicada a 45 madres adolescentes, 86,6\% de las cuales consideró que los ítems eran comprensibles. Conclusión: Hubo equivalencias semántica, idiomática, cultural y conceptual satisfactorias para las versiones del cuestionario, pertinente y comprensible para la cultura portuguesa. Sin embargo, es imprescindible evaluar sus propiedades psicométricas.

Descriptores: Traducción; Responsabilidad Parental; Necesidades y Demandas de Servicios de Salud; Aprendizaje Basado en Problemas; Adolescente.

\section{CORRESPONDING AUTHOR Paula Sarreira-de-Oliveira E-mail: psarreira@egasmoniz.edu.pt}

\section{INTRODUCTION}

Postpartum is a transition period in which new mothers face a variety of challenges. In this stage, new competencies and information are demanded from women in order to manage their needs and those of their infants ${ }^{(1)}$. It is known that mothers' age, education level, professional status, economic capacities, and parity are significantly associated with the need for and priority of learning to care for themselves and their children ${ }^{(1-2)}$. In this context, the relationships of trust established with nurses are also valued $^{(3)}$, and the fact that nurses are culturally sensitive to support the social needs and can identify the barriers to health care for adolescent mothers makes them facilitators in the process of transition to motherhood ${ }^{(4)}$. However, there are specific concerns expressed by them related to clinical problems that do not come up in the first 24 hours after birth. These problems are associated, namely, with tiredness in the postpartum period and with insufficient knowledge of newborn care $^{(5)}$. The short length of hospitalization, low availability and tiredness of new mothers are challenges for nurses, especially in providing the necessary education and support to promote motivation and self-confidence ${ }^{(6)}$.

In order to have a comprehensive overview of the knowledge presented by adolescent mothers and create mechanisms for future interventions, Jordan researchers developed and validated the Postpartum Learning Needs (PLN) to assess knowledge that is most important for mothers regarding self-care and care for their newborns. It is important to adopt valid tools to assess knowledge that is most important for mothers to care for themselves and their children so that strategies considered essential be established in order to adapt them to the maternal role.

\section{OBJECTIVE}

To describe the process of translation to the Portuguese language and cultural adaptation of the PLN to the Portuguese context, initially verifying its applicability to the Portuguese reality, through the face and content validity of the adapted version.

\section{METHOD}

\section{Ethical aspects}

The research proposal was approved by the Human Ethics Research Committee of the Lisbon Portuguese Catholic University on December $13^{\text {th }}, 2013$. The study was authorized by the National Committee for Data Protection (Comissão Nacional de Proteção de Dados - CNPD) on October 28 ${ }^{\text {th }}, 2014$.
Lastly, each hospital institution where the research took place also provided authorizations.

\section{Study design, setting, and period}

In terms of investigation methodology, this study is considered non-experimental, therefore being considered a methodological study, observing the guidelines by Beaton et al. ${ }^{(7)}$ The study was developed in 2014, in hospitals of the Lisbon Metropolitan Area.

This study derived from a nursing investigation titled "Motherhood in Adolescence" and results from a bibliographic search regarding the care needs adolescent mothers valued for themselves and their children. The authors chose to refer to a Jordanian article, whose aim was to outline the adaptation of a self-applicable questionnaire for assessment of mothers' knowledge needs. The process of translating and adapting the Postpartum Learning Needs began after analysis of the article. Thus, there were the stages of translation to the Portuguese language, synthesis of the translations, back-translation to the original language, assessment by an expert committee, and pre-testing, which was all documented in a written report.

Initially, it could be found that the questionnaire is presented in English and comprises 50 items. Responses follow a 4-point Likert scale, ranging between 1 and 4, in which $1=$ not important, $2=$ little important, 3 = important, and 4 = very important.

The questionnaire is divided into two subscales, in which 23 items are related to maternal self-care and 27 items are related to newborn care. In the first subscale, 13 of the items address the learning needs that mothers value the most in relation to self-perceived physiological needs, care for the lochia, episiotomy care, care for the breasts, nutrition and diet, physical exercise, medication, medication for pain relief, among others, and 10 items related to psychoaffective and social needs, such as sexuality, emotional lability, marriage, and adequate organization and management of time and stress.

The second subscale addresses issues related to the newborns. In short, of the 27 items related to newborn care, 14 items address their physical/physiological development, more directly, feeding, temperature measurement, infant diseases, among others, 7 items address aspects related to psychoaffective issues, such as choice of names, of toys, how to dress or when to take infants for strolls and, lastly, 6 items are related to vigilance and anticipatory care, such as apppointments, health surveillance, immunization and when to look for medical care. According to needs felt, adolescent mothers are asked to rate the priority of the knowledge attributed to the items related to self-care and newborn care.

The original questionnaire presented a Cronbach's alpha coefficient in the maternal subscales of 0.86 and in the newborn 
subscales of 0.93, which highlighted its adequacy for application to the target public.

\section{Study protocol}

The process was started by two foreign language translators, who had Portuguese as their first language and were fluent in English. One of the translators was familiar with the work to be translated, while the second translator was not informed of the translation objectives (T1 and T2). At the end of this stage, versions $\mathrm{T} 1$ and $\mathrm{T} 2$ of the PLN were obtained. These two versions were analyzed and compared, with vocabulary variations being resolved by consensus among the researchers and translators, consequently resulting in a synthesis of these translations, which was titled T12.

In order to advance the process, at the third stage, the synthesis of the first two translations (T12) was back-translated independently by two different bilingual translators. These translators had English as their first language, being fluent in Portuguese and living in Portugal, one of them with Nursing training and the other with no training in the health field. None of these translators participate in the first stage of the translation process and they did not know the original version of the questionnaire.

This stage's conclusion originated two new English versions of the questionnaire ( $R 1$ and $R 2$ ). These versions were analyzed, with discrepancies solved through rulings presented by the translators, enabling any alteration proposal to be applied to the Portuguese version. A consensus version (CV) resulted from this appreciation. Considering that there were no important discrepancies, it was concluded that the synthesized Portuguese version of the translations was adequate to be sent to the expert committee.

For the next stage, aiming for apparent or face validity, T12 content and creation of the pre-final version for pre-testing, the synthesis of the translated version was appreciated by a group of experts in the field, with specific knowledge of the work assessed by the questionnaire.

\section{Population and sample}

The expert committee comprised three specialist nurses with a master's degree in Maternal Health and Obstetrics, two of them attending doctorate programs in Nursing and one specialist nurse with a master's degree in Child Health and Pediatrics. As inclusion criterion, all specialists had over 15 years experience in the field of maternal health and obstetrics. These experts assessed aspects such as the assessment of each questionnaire item regarding equivalences in semantics, idioms, concepts and culture, making suggestions for changes when they saw it fit and that had not been suggested until that moment. Assessment of aspects not yet contemplated, such as structure, layout, and instructions for filling the questionnaire was also requested.

Before confirming that a new questionnaire is ready for application, a mandatory pre-test or pilot study must be conducted. Thus, the Portuguese version was applied to a convenience sample of 45 adolescent mothers, who met the inclusion criteria of being aged between 10 and 19, hospitalized in the services, in immediate postpartum, in the Lisbon metropolitan area hospitals, in Portugal, and who agreed with and signed a free and informed consent form. It should be emphasized that this consent form was requested from parents or legal guardians, along with consent from the young women themselves, whenever mothers were below the age of 18 .

Mothers received along with the Portuguese version of the questionnaire, instructions on how to fill it. Six adolescent mothers were excluded, because they had not filled more than $50 \%$ of the questionnaire, which left us with a final sample of $39(86.6 \%)$ adolescent mothers. Afterward, the questionnaire assessment instruments filled in by each respondent were analyzed, checking the level of comprehension and the need for changes in items.

In the pre-testing, the software Statistical Package for the Social Sciences (SPSS), version 19.0, was used to compile and conduct the descriptive analysis of data regarding the application of the Postpartum Learning Needs.

\section{RESULTS}

The assessment of different questionnaire translations was conducted for each item in particular. Some items comprised a combination of terms from the two versions, resulting from independent translations, considering that, in the translation process, there were no divergent words or expressions, although less expressive vocabulary variations were present, which were observed and solved after discussion and consensus among the involved translators. In order to conduct this stage, items that better corresponded to the initial objective were selected, in other words, items that preserved the semantic equivalences ("do the words have the same meaning?") idiomatic equivalence ("is there equivalence in slangs and colloquial expressions?"), conceptual ("are concepts homogeneous between cultures?") and that presented simple and direct vocabulary.

In the expert assessment stage, the main changes recommended by them were related to terminology and expressions employed, related to the possibility of being generalized to different contexts and populations, more concretely if the expressions were adequate to the population, if the arrangement of the questions and the size of the questionnaire were adequate in relation to the sought information. By consensus, item 8 , related to "circumcision", was removed, since its practice is not part of the Portuguese culture. All suggestions were analyzed and accepted after analysis, reaching the pre-final version of the questionnaire.

Regarding the pre-testing, it is noteworthy that the subjects were asked to express their assessment of writing clarity and pertinence of items, in addition to the possibility of recommending changes. Thus, considering the aspects associated with clarity and pertinence of assessed items, it was possible to deduce that over $90 \%$ involved a large part of the questionnaire, except item 23 , regarding "cultural practices during the birth period", in which $70 \%$ of individuals claimed to understand the questioned element. It was also found that there was no need for semantic adequation, thus, they could be kept in the questionnaire, since the understanding sought for each item was reached. Only $20 \%$ of participants expressed doubts or suggested changes to improve comprehension or the questionnaire's content.

Thus, after what was described of the translation and cultural adaptation process, there was the final version of the questionnaire, presented in Charts 1 and 2 . 
Chart 1 - Final version of the Postpartum Learning Needs in the subscale "Maternal needs", after all stages of the cultural translation process, Lisbon, Portugal, 2016

\begin{tabular}{|l|l|l|l|l|}
\hline \multicolumn{1}{|c|}{$\begin{array}{c}\text { PLN (Postpartum Learning Needs) } \\
\text { Maternal needs } \\
\text { Knowledge about: }\end{array}$} & NI & LI & I & VI \\
\hline $\begin{array}{l}\text { 1. Cuidados com a sutura do períneo /vaginal } \\
\text { (Episiotomy care) }\end{array}$ & & & \\
\hline $\begin{array}{l}\text { 2. Cuidados com a sutura abdominal (em caso } \\
\text { de cesariana) (Abdominal incision care - in } \\
\text { case of a C-section) }\end{array}$ & & & \\
\hline
\end{tabular}

3. Cuidados com a higiene vaginal (Vaginal hygiene care)

4. Perdas de sangue depois do parto (Lóquios) (Vaginal discharge - Lochia)

5. Próximo período menstrual (Next menstrual period)

6. Funcionamento intestinal ("prisão de ventre", hemorroidas) (Bowel function - constipation/ hemorrhoids)

7. Funcionamento vesical (dificuldade em urinar por dor ou ardor) (Bladder function - difficulty urinating due to pain or burning sensation)

8. Nutrição/Alimentação (o que comer enquanto dá de mamar) (Nutrition - what to eat while breastfeeding)

9. Exercício físico (Recuperação física pós-parto) (Physical exercise - after birth physical recovery)

10. Dores depois do parto (After birth pains)

11. O que deve ou pode tomar de medicamentos (What medications to take)

12. Complicações no pós-parto/puerpério (Postpartum complications)

13. Alterações de humor no pós-parto/puerpério (Ex.: muita tristeza) (Postpartum mood changes - e.g. much sadness)

14. Cuidados com as mamas após o parto (After birth breast care)

15. Tomar banho (Bathing)

16. Cansaço/ Fadiga pós-parto (Postpartum tiredness/fatigue)

17. Relacionamento com o companheiro (Relationship with husband)

18. Estratégias a adotar para ser uma "boa mãe" em casa/ domicílio (Strategies to adopt to be a good mother at home)

19. Organização do tempo (Time management)

20. Planeamento familiar/Métodos contracetivos (Family planning/contraceptive methods)

21. Alterações no relacionamento sexual/Retorno da atividade sexual (Intercourse/sexual changes - sexual life resumption)

22. Realização de práticas relacionadas com a tradição (Postpartum cultural practices)

23. Acompanhamento pós-parto/ Consulta de revisão de parto (Follow up postpartum care / birth review appointment)

Note: $\mathrm{NI}=$ Not important; $L I=$ Little important; $I=I$ mportant; $V I=$ Very important
Chart 2 - Final version of the Postpartum Learning Needs in the subscale "Infant needs", after all stages of the cultural translation process, Lisbon, Portugal, 2016

\begin{tabular}{|l|}
\hline \multicolumn{1}{|c|}{ PLN (Postpartum Learning Needs) } \\
Infant needs \\
Knowledge about: \\
\hline $\begin{array}{l}\text { 1. Alimentação da criança (Infant feeding) } \\
\text { a.leitamento materno/amamentação } \\
\text { (Breastfeeding) }\end{array}$ \\
\hline $\begin{array}{l}\text { b. Alimentação artificial com a mamadeira } \\
\text { (Bottle feeding) }\end{array}$ \\
\hline
\end{tabular}

2. Eliminação infantil (relacionada com as fezes e com a urina) (Infant elimination - related to feces and urine)

3. Arrotar (Burping)

4. Banho (Bathing)

5. Mudança da fralda (Diaper changing)

6. Cuidados com a pele (Skin care)

7. Cuidados com o coto umbilical (Cord care)

8. Posição na cama (deitar de lado ou de costas) (Position in bed - on the side or on the back)

9. Doenças das crianças (Infant diseases)

10. Avaliação/medição da temperatura (febre) (Temperature assessment - fever)

11. Icterícia do bebé (bebé amarelo) (Infant jaundice - yellowish baby)

12. Segurança da criança (Infant safety)

13. Teste do pezinho (Bloodspot test)

14. Crescimento e desenvolvimento da criança (Infant's growth and development)

15. Choro (Crying)

16. Medicação (Medication)

17. Vestuário da criança (Infant's clothing)

18. Passear o bebé (Taking infant outside)

19. Escolha dos brinquedos para o bebé (Choosing toys for infant)

20. Escolha do nome do bebé (Choosing infant's name)

21. O que fazer quando vêm visitar o bebé (What to do when having visitors)

22. Sono do bebé (Infant sleep)

23. Relação com os irmãos (rivalidades/ ciúmes entre irmãos) (Relationship with siblings - sibling rivalry/jealousy)

24. Saber quando recorrer ao médico em caso de doença do filho (When to call the physician about infant's illness)

25. Vacinação infantil (Infant immunization)

26. Realização de práticas no bebé relacionadas com a tradição (Infant cultural practices)

Note: $\mathrm{NI}=$ Not important; $\mathrm{LI}=$ Little important; $I=I$ mportant; $V I=$ Very important

\section{DISCUSSION}

With the intention of developing a faithful questionnaire, unprecedented and useful to be introduced to the realities of adolescent mothers in Portugal, the translation and cultural 
adaptation method of the Postpartum Learning Needs was a process conducted systematically and considered satisfactory in all of its stages.

Regarding structure and presentation of the questionnaire, it was opted to preserve the configuration and appearance presented in the model proposed by the original version, since no difficulties or errors were found in relation to how it was filled.

No important discrepancies between the two translations in our study were found. However, in the case of some words and expressions, the suggestions made by the translator with no knowledge of the health field were chosen, since this translation was more appropriate and of clearer comprehension and understanding for the target population of the questionnaire. As for the translations synthesis, it is emphasized that it reached its aim, considering the conservation of the questionnaire free of any influences for the creation of the consensual version. In the back-translation stage, no problems were found that could interfere in the method's correctness or that were not in agreement with the Portuguese context.

As for the stage of questionnaire assessment by the experts' committee, adjustments considered crucial were made and, afterward, assessed by the study's investigators, according to cultural relevance. Thus, after assessing the difficulties, the items were modified.

Although the results were considered acceptable for comprehension of the items, it is noteworthy that some items are complex in their technical terminology and difficult to translate. Thus, this research found the need to perform some conceptual adjustments in some words and expressions which interfered in their semantic equivalence, and consequently, in the understanding of information on the original questionnaire ${ }^{(8)}$.

Related to the pre-testing phase, the 39 respondent adolescent mothers were instructed to expose any difficulties related to comprehension of the items. In this sense, it is considered essential for this questionnaire to be assessed by adolescent mothers of different ages (inside the age group to which the questionnaire is aimed), as well as residing in various areas/ regions, since the questionnaire will be available to be applied to adolescent mothers in this life cycle in Portugal after validation. Although the questionnaire was translated, backtranslated and discussed among professionals who were experts in the field, there is nothing more real and humane than subjects' own perception facing the object of study.

However, in order to minimize possible response biases, the questionnaire was handed in by the researcher, since this is proven to be a crucial moment for resolving ambiguities and verifying interpretation issues found by respondents, in addition to enabling an estimation of the length of time to be suggested for the questionnaire completion ${ }^{(9)}$. It can also be inferred that, in the sample, age can also be considered a bias, which is difficult to minimize. When it was impossible for the participants to respond autonomously to the questionnaire, either because of illiteracy or because of physical or mental issues, information was obtained by the researcher, who filled in the questionnaire. In this case, the questions were already previously decided in the questionnaire, with the researcher just reading them and writing down the subjects' responses, without adding new questions during the interview. An advantage of this verbal method is that the response rates are higher. When self-written information is collected, self-applicable questionnaires are employed, in other words, subjects read and respond by themselves, with no need for interviewers.

Lastly, "usability"(9) of the questionnaire was always in mind, considering the effort associated with participants, namely, in relation to time and costs involved.

In short, aspects related to comprehension, pertinence, and clarity for each item were investigated initially through analysis and suggestions from specialists and, afterwards, through participation of the target population in the pre-testing phase. Agreement between the expert committee and the target population was found regarding items presented in the original questionnaire, regarding the Portuguese reality.

\section{Study limitations}

The age of participants in the sample was one of the main study limitations. The obtained results until now indicate that the PLN instrument is adaptable to the Portuguese culture, with possibility of moving to the next phase of application to individuals and determination of psychometric characteristics.

\section{Contributions to the Nursing field}

Regarding nursing knowledge, it can be said that the application of the questionnaire will enable a range of knowledge presented by adolescent mothers to care for themselves and their infants, making it possible to create strategies for future interventions.

\section{CONCLUSION}

The process of translation and cultural adaptation of the Postpartum Learning needs to the Portuguese culture followed internationally recommended stages and was conducted successfully. In other words, we can conclude that the translation and cultural adaptation processes kept important characteristics of validity, considering that, through the results found, it can be said that the principles of comprehension, agreement, clarity, and pertinence were reached, even after necessary modifications.

\section{REFERENCES}

1. Obeisat SMK, Gharaibeh MK, Aishee A. Postpartum learning needs: perceptions of Jordanian mothers and nurses. Europ J Soc Sci [Internet]. 2012 [cited 2015 Aug 12];30(4):535-46. Available from: http://www.europeanjournalofsocialsciences.com

2. Reis CT, Laguardia J, Martins M. Translation and cross-cultural adaptation of the Brazilian version of the Hospital Survey on Patient 
Safety Culture: initial stage. Cad Saúde Pública [Internet]. 2012[cited 2015 Aug 12];28(11):2199-2210. Available from: http:// www.scielo.br/pdf/csp/v28n11/19.pdf/doi.org

3. Gyesaw NYK, Ankomah A. Experiences of pregnancy and motherhood among teenage mothers in a suburb of Accra, Ghana: a qualitative study. Int J Womens Health[Internet]. 2013[cited 2014 Jun 05];5. Available from: https://www.ncbi.nlm.nih.gov/pmc/ articles/PMC3829679/pdf/ijwh-5-773.pdf/doi: 10.2147/IJWH.S51528

4. Cypher R. Collaborative approaches to prenatal care: strategies of successful adolescent programs. J Perinat Neonatal Nurs[Internet]. 2013[cited 2015 Aug 12];27(2):134-44. Available from: www.ncbi.nlm.nih.gov/pubmed/23618934/doi/10.1097/ JPN.0b013e31828ecc40

5. Carvalho REFL, Cassiani SHB. Questionário Atitudes de Segurança: adaptação transcultural do Safety Attitudes Questionnaire - Short Form 2006 para o Brasil. Rev Latino-Am Enfermagem[Internet]. 2012[cited 2015 Dec 8];20(3)[8 telas]. Available from: www.scielo.br/pdf/rlae/v20n3/pt_a20v20n3.pdf

6. DeVito J. How adolescent mothers feel about becoming a parent. J Perinat Educ [Internet]. 2010[cited 2012 Jun 8];19(2):25-34. Available from: https://www.ncbi.nlm.nih.gov/pmc/articles/PMC2866436/

7. Beaton D, Bombardier C, Guillemin F, Ferraz MB. Guidelines for the process of cross-cultural adaptation of self-report measures. Spine [Internet]. 2000[cited 2013 Jun 14];25(24):3186-91. Available from: https://www.ncbi.nlm.nih.gov/pubmed/11124735

8. Almeida L, Freire T. Metodologia da Investigação em Psicologia e Educação. 5 ed. Braga: Psiquilibrios; 2008.

9. Watts MCNC, Liamputtong P, Mcmichael C. Early motherhood: a qualitative study exploring the experiences of African Australian teenage mothers in greater Melbourne, Australia. BMC Public Health. [Internet]. 2015[cited 2014 Jun 16];15:873. Available from: https://www.ncbi.nlm.nih.gov/pmc/articles/PMC4566485/pdf/12889_2015_Article_2215.pdf/doi/10.1186/s12889-015-2215-2 